\title{
Environmental Risk Assessment of Heavy Metals by Exploring Chemical Fractions, Leachability, Bioavailability in Road Dusts from Steel-Industrial City (Anshan), Northeastern China
}

\section{Yutong Zong}

Zhejiang University

Qing Xiao

Zhejiang University

\section{Zaffar Malik}

The Islamia University of Bahawalpur Pakistan

Shenggao Lu ( $\square$ lusg@zju.edu.cn )

Zhejiang University https://orcid.org/0000-0002-4246-3623

\section{Research Article \\ Keywords: Road dusts, heavy metals, chemical fraction, leachability, bioavailability}

Posted Date: May 27th, 2021

DOI: https://doi.org/10.21203/rs.3.rs-431433/v1

License: (9) This work is licensed under a Creative Commons Attribution 4.0 International License. Read Full License 


\section{Abstract}

This study evaluated chemical fractions, potential leachability, and bio-accessibility of heavy metals $(\mathrm{Cr}, \mathrm{Cu}, \mathrm{Cd}, \mathrm{Ni}, \mathrm{Pb}$, and $\mathrm{Zn})$ in road dusts from the steel-industrial city (Anshan), Northeastern China. Chemical fractions of heavy metals were determined using Tessier sequential extraction method. The environmental risk assessment was evaluated using short-term extraction tests: TCLP, PBET, and $\mathrm{CaCl}_{2}$. Sequential extraction analysis reveals that $\mathrm{Cr}$ and $\mathrm{Ni}$ primarily existed in residual form. The non-residual fraction of heavy metals decreased in the order of $\mathrm{Zn}$ (average 57.78\%) > Cu (39.16\%)> Pb (30.73\%) $\approx \mathrm{Cd}(30.67 \%)>\mathrm{Ni}(19.06 \%)>\mathrm{Cr}(8.7 \% \%)$. The results showed that $\mathrm{Cd}, \mathrm{Cu}, \mathrm{Zn}$ and $\mathrm{Pb}$, which were extremely concentrated in potentially mobile fractions, had highly potential environmental risks. The mobility of $\mathrm{Cd}$ and $\mathrm{Zn}$ was usually higher than those of $\mathrm{Cr}, \mathrm{Cu}, \mathrm{Pb}$ and $\mathrm{Ni}$, which means that $\mathrm{Cd}$ and $\mathrm{Zn}$ have higher hazardous to ecosystem. The order of bioavailability identified by PBET method was generally $\mathrm{Zn}>\mathrm{Cd}>\mathrm{Pb}>\mathrm{Ni}>\mathrm{Cu}>\mathrm{Cr}$. There was a significantly relationship between PBET, TCLP-test and bioavailable parts (F1+F2+F3+F4, SUM4) of sequential extraction, respectively. Multiple linear regression analysis indicated that toxicity and bioavailability of heavy metals were not only depended on RDs properties, but also lied on the total heavy metals.

\section{Introduction}

Road dusts (RDs) is an important heavy metal carrier immigrating on the urban surface mainly through atmospheric sedimentation and human emissions. RDs particles were regarded as an indicator on effecting air quality and human health, such as providing air particle materials (e.g. $\mathrm{PM}_{2.5}$ and $\mathrm{PM}_{10}$ ), absorbing organic pollutant, accumulating heavy metals and so on. Numerous researches have been done to study the heavy metals in RDs particles (Barrett et al. 2010; Duong and Lee 2009; Ewen et al. 2009; Fujiwara et al. 2011; Gunawardana et al. 2012; Kumar et al. 2014; Lee et al. 2015; Norouzi et al. 2016; Świetlik et al. 2015; Xiao et al., 2020). Lee et al. (2013) reported the study of heavy metals ( $\mathrm{As}, \mathrm{Cd}, \mathrm{Cu}, \mathrm{Pb}, \mathrm{Sb}$ and $\mathrm{Zn}$ ) in RDs and demonstrated that anthropogenic inputs contributed much more than originating from earth's crust. RDs particles were much fine solid phase and almost ubiquitous, which can be easily floated and transported by wind, possibility entrancing the human body by ingestion, dermal contact, or breathing. Thus, these heavy metals in RDs particles were the potential hazards to environment safety and human health.

Recently, numerous investigators studied the total heavy metals in RDs particles and evaluated the environment risks (Faiz et al. 2009; Okorie et al. 2012; Pereira et al. 2007; Shi et al. 2008; Wei et al. 2015; Xiao et al., 2020). However, the total concentration of heavy metals cannot be fully evaluated the potential risk in RDs particles. Obviously, the bioavailability, toxicity and available of heavy metals not only depended on their total concentration, but also related to the chemical stability (Zong et al., 2016). It is well known that the total content of heavy metals can provide limited information on their mobility and bioavailability (Poggio et al. 2009; Rao et al. 2008). Otherwise, the potential hazard of heavy metals to environment safety and human health is primarily dependent on their availability and bioaccessibility (Duong et al. 2009; Gleyzes et al. 2002; De Miguel et al. 2007; Madrid et al. 2008; Menzies et al. 2007). Therefore, identification of the main binding sites for heavy metals in RDs particles, as well as their partitioning over the different solid phases present is imperative for assessing environmental quality and human health.

Thus, more and more researchers have done the leachability and bioaccessibility in RDs particles. Chemical fractions of heavy metals in RDs particles and sediments were mostly determined by sequential extraction procedure: Tessier method (Preciado and Li 2006) and the BCR method (Ewen et al. 2009). Meanwhile, various simulation tests were carried out to study the availability, mobility and bioaccessibility of heavy metals in solid phase, such as EDTA (Groenenberg et al. 2010), TCLP (Madrid et al. 2007), PBET (Poggio et al. 2009), $0.43 \mathrm{M} \mathrm{HNO}_{3}$ (Tipping et al. 2003), and $0.01 \mathrm{M} \mathrm{CaCl}_{2}$ (Peijnenburg et al. 2007). Meanwhile, several methods have also been applied to assess the oral bioaccessibility of heavy metals, especially for Pb and As (Li et al. 2015a; Li et al. 2015b). Houba et al. (2000) and Meers et al. (2007) reported that $\mathrm{CaCl}_{2}$ extractable fraction was a good indicator and predictor for plant uptake. The TCLP procedure is commonly used by regulatory agencies for assessment of leaching risks of heavy metal elements in soil and sludge (US Environment Protection Agency (USEPA), 1993). Physiologically based extraction test (PBET) was applied to evaluate the heavy metals bioaccessibility, which was a simple and fast screening test, especially for $\mathrm{Pb}$ (Lu et al. 2009; Mercier et al. 2002). In particular, the heavy metals chemical species obtained by $\mathrm{CaCl}_{2}$, TCLP and PBET are widely applied to simulate availability, mobility and bioaccessibility, respectively. Meanwhile, the chemical fractions of heavy metals though sequential extractions are also suitable for assessing the mobility and availability.

Rapid economic growth, heavy traffic, urbanization, and increasing population have caused modern cities to suffer from many serious air problems, especially the air pollution with heavy metals. However, few studies were done to investigate the detail characterization and the basic properties on heavy metal mobility and bioaccessibility. The determination of the different ways of binding gives more information 
on trace metal mobility, as well as on their availability or toxicity, in comparison with the total element content. In the present study, the chemical speciation of heavy metals $(\mathrm{Cr}, \mathrm{Cd}, \mathrm{Cu}, \mathrm{Ni}, \mathrm{Pb}$ and $\mathrm{Zn}$ ) in road dust samples was studied by using three different leaching tests. The chemical speciation was also done to investigate the potential mobility and bioavailability. Thus, the objectives of this research were to 1) access the distribution and environmental risks of heavy metals using sequential chemical extraction; 2) to correlate metals mobility by using different short-term batch extraction procedures; 3 ) to evaluate the effect of road dust properties on the leachability of metals; and 4) to explore the mechanisms of heavy metals dissolution in RDs.

\section{Materials And Methods}

\subsection{Road dust samples}

Eighty-nine road dust samples were collected from different areas of Anshan city, Liaoning Province, China. The road dust samples were collected by gently sweeping using clean plastic dustpans and brushes. Extraneous matter such as small pieces of brick, paving stone, leaves and other debris were removed. Then, the samples were dried in an oven at $40^{\circ} \mathrm{C}$ for 3 days, sieved to less than $250 \mu \mathrm{m}$ size, and stored in polypropylene bottles. The detail information on study area can be found in our previous research (Xiao et al. 2015).

The basic properties of RDs samples were determined by standard procedures (Zhang and Gong 2012). pH and Ec was measured in water (solid/water ratio of 1:2.5). Alkali-hydrolyzable nitrogen $\left(\mathrm{NH}_{4}{ }^{+}\right)$was determined by the $\mathrm{NaOH}$ hydrolyzable method. Carbonate was measured by adding $\mathrm{HCl}$ to RDs, and the volume of $\mathrm{CO}_{2}$ was measured with a gas apparatus. Total carbon (TC), total phosphorus (TP) and total sulfur (TS) were quantified with an elemental analyzer (Vario Micro, Elementar Inc., Germany). The Fe content was measured by inductively coupled plasma-atomic emission spectroscopy (iCAP6300DUO, Thermo Electron Corporation) and shown in the form of $\mathrm{Fe}_{2} \mathrm{O}_{3}$. Particle size distribution (PSD) of RDs samples was determined by a combination of wet sieving and pipette methods (Zong et al., 2016b). The RDs samples were partitioned into three size fractions: $>50 \mathrm{um}, 2-50 \mathrm{um}$ and $<2 \mathrm{um}$, respectively. Standard reference material (GBW07401) was periodically used for quality assurance of the RDs heavy metal measurement.

\subsection{XRD}

X-ray diffraction (XRD) was used to identify the crystalline phase in RDs particles. X-ray diffraction analysis was performed on nonoriented powder RDs samples using Cu K radiation ( $45 \mathrm{kV}, 300 \mathrm{~mA})$ on a Rigaku X-ray diffractometer. The diffraction pattern was recorded from $10^{\circ}$ to $80^{\circ} 2 \theta$ at a speed of $0.2^{\circ} 2 \theta / \mathrm{min}$.

\subsection{Selective sequential extraction procedure}

The sequential chemical extraction process was performed according to the method proposed by Tessier et al. (1979), which defined five types of chemically extractable heavy metals: (1) water-soluble/exchangeable (F1); (2) carbonate-bound (F2); (3) Fe- Mn oxide-bound (F3); (4) organically bound (F4); and (5) residual (F5). A brief step was interpreted in table S1. The detail procedure can be seen in our previous study (Zong et al. 2016a).

\section{4. $\mathrm{CaCl}_{2}$, TCLP, and PBET extractions}

$\mathrm{CaCl}_{2}$ extractable methods were obtained according to Houba et al. (1986). $2 \mathrm{~g}$ road dust sample was weighted into polypropylene bottles and added with $20 \mathrm{ml} \mathrm{CaCl}_{2}(0.01 \mathrm{M})$ leaching solution, followed a $2 \mathrm{~h}$ shaking at room temperature. The extracts were filtered with the $0.45 \mu \mathrm{m}$ filter paper.

Toxicity characteristic leaching procedure (TCLP) extraction was performed on soil samples (U.S. EPA 1992). The TCLP leaching solution was consisted of $0.1 \mathrm{M}$ glacial acetic acid and $0.0643 \mathrm{M} \mathrm{NaOH}$ and had a final $\mathrm{pH}$ of $4.93 .1 \mathrm{~g}$ road dust sample was weighted into polypropylene bottles and added with $20 \mathrm{ml}$ of TCLP leachate. The bottles were shaken for $18 \mathrm{~h}$ at room temperature. The extracts were filtered with the $0.45 \mu \mathrm{m}$ filter paper.

Physiologically based extraction test (PBET) extractable content was obtained according to Ruby et al. (1996). PBET extraction was conducted by weighing $1.0 \mathrm{~g}$ dust into polypropylene bottles, adding $100 \mathrm{ml}$ PBET (1L PBET solution contained $1.25 \mathrm{~g}$ pepsin, $0.5 \mathrm{~g}$ citrate, $0.5 \mathrm{~g}$ malate, $0.42 \mathrm{ml}$ lactic acid, and $0.5 \mathrm{ml}$ acetic acid, $\mathrm{pH}=2.5)$ solution, following $1 \mathrm{~h}$ shaking $(100 \mathrm{rpm})$ at water bath $\left(37^{\circ} \mathrm{C}\right)$. The mixture was centrifuged, and the supernatant was filtered through with the $0.45 \mu \mathrm{m}$ filter paper.

Metal concentrations were determined by ICP-AES (ICP-AES, ICAP6300DUO, Thermo Electron Corporation). Standard reference material (GBW07401) was periodically used for quality assurance of the RDs heavy metal measurement. 
The leachability of heavy metals in RDs samples was calculated by the following equation.

The leachability of metals in $\mathrm{RDs}(\%)=\left[\left(\mathrm{C}_{\text {metal }}, \mathrm{mg} / \mathrm{L}\right)(\mathrm{V}, \mathrm{L}) /\left(\mathrm{Q}_{\text {metal }}, \mathrm{mg} / \mathrm{g}\right)(\mathrm{m}, \mathrm{g})\right] \times 100 \%$, where $\mathrm{C}$ is the metal concentration in the extractable solution and $\mathrm{Q}_{\text {element }}$ is the metal content in the RDs.

\subsection{Data analysis}

Descriptive statistics (mean and standard deviation) of RDs properties were performed applying Microsoft Excel for Windows 10. Statistical analyses were conducted using SPSS 16.0 for Windows (SPSS Inc.) and plotted by Origin Version 8 (OriginLab Corporation). The Spearman correlation coefficient, $r$, was used to measure the relationship between two quantitative variables. All results were expressed as averages of three replicates with standard deviation.

\section{Results And Discussion}

\subsection{Basic properties of RDs}

The basic properties of RDs samples were shown in table 1. The pH value of RDs ranged from 7.29 to 10.19 , with the average value of 8.44. The road dust contained high total carbon (TC), ranged from 16.91 to $216.61 \mathrm{~g} \cdot \mathrm{kg}^{-1}$ on the average of $47.19 \mathrm{~g} \cdot \mathrm{kg}^{-1}$. The total phosphorus (TP) content varies from 0.06 to $0.55 \mathrm{~g} \cdot \mathrm{kg}^{-1}$ with mean value of $0.27 \mathrm{~g} \cdot \mathrm{kg}^{-1}$. The total sulfur (TS) content varies from 0.33 to $2.06 \mathrm{~g} \cdot \mathrm{kg}^{-1}$ with an average value of $0.71 \mathrm{~g} \mathrm{~kg}^{-1}$. The average concentration of $\mathrm{NH}_{4}^{+}$is $0.16 \mathrm{~g} \cdot \mathrm{kg}^{-1}$ in all RDs samples. Particle size distribution of RDs showed that dust samples had high amount content of $>50 \mu \mathrm{m}$ ranging from 184.6 to $684.7 \mathrm{~g} \cdot \mathrm{kg}^{-1}$, whereas the amount of $50-2 \mu \mathrm{m}$ and $<2 \mu \mathrm{m}$ composition ranged from 57.52 to 377.48 and from 34.43 to $282.21 \mathrm{~g} \cdot \mathrm{kg}^{-1}$, respectively. The average particles diameter contents of RDs samples were $59.28 \%$ for $>50 \mu \mathrm{m}, 25.44 \%$ for $50-2 \mu \mathrm{m}$, and $15.28 \%$ for $<2 \mu \mathrm{m}$, respectively. High Fe oxides (in the form of $\mathrm{Fe}_{2} \mathrm{O}_{3}$ ) content was observed for the dust samples, ranged from 6.26 to $70.68 \%$ with an average of $16.74 \%$. The content of $\mathrm{CaCO}_{3}$ ranged from 1.99 to $19.36 \%$ with mean value of $10.62 \%$. Otherwise, extremely high content of heavy metals were also observed in RDs samples (Xiao et al., 2020). These basic properties of RDs in high pH, TC, and Fe oxides content might affect the chemical fraction and bioavailability of heavy metals.

The XRD patterns of selected representative RDs samples are displayed in Fig.1. X-ray diffraction pattern confirmed that quartz, calcite, albite, kaolinite, chlorite, muscovite, hematite, and magnetite are the seven main kinds of minerals in RDs particles. A small amount of cronstedtite and sanidine could also be found in the RDs particles. Upon semi-quantitatively analyzing the intensity of each mineral in XRD patterns, it confirmed that hematite and magnetite are generally the dominant iron species in RDs particles. The high Fe oxides in RDs could aggravate the heavy metal environment risk due to their lattice structure and adsorb heavy metals on their surface. In our previous study, iron particles, regarding as the carries of heavy metal, can be used as an indirect indicator to evaluate the heavy metals contamination and identification of pollution source (Zong et al. 2017).

\subsection{Chemical fractions of heavy metals}

The chemical fraction of heavy metals in RDs samples is showed in Fig.2. The five chemical forms (exchangeable, carbonate bound, oxidizable bound, organically bound, and residual fraction) are expressed as the relative percentages.

Cadmium: The residual fraction of $\mathrm{Cd}$ accounted for $47.19-92.26 \%$, and exchangeable form was 0.56-9.47\%. The domain chemical forms for $\mathrm{Cd}$ is the residual (69.33\%), followed by the carbonate bound (10.88\%) and oxidizable bound (8.61\%), and average 6.94 and $4.25 \% \mathrm{Cd}$ is associated with organically and exchangeable fractions, respectively. Obviously, relative low exchangeable Cd in RDs particles was observed.

Copper. The residual fraction of $\mathrm{Cu}$ accounted for 47.16- 80.87\%, and the exchangeable form was $0.19-1.54 \%$. The dominating chemical form for Cu was the residual fraction (60.84\%), the organically bound (37.34\%) was of secondary important, followed by the carbonate bound (2.58\%), and a very small proportion of Cu was found to be exchangeable (0.88\%) and oxidizable bound (0.26\%). The organically forms of Cu contained the highest percentages compared with other heavy metals. The result implied that Cu was mainly bound to organic matter, which agreed with the results of other reports (Peng et al. 2009; Świetlik et al. 2015). Thus, the chemical fractions of Cu are unstable and easily changed under strong oxidizing or strong reducing conditions.

Lead: The greatest amount of $\mathrm{Pb}$ is associated with the residual fraction, averaging $69.27 \%$. The oxidizable bound, averaging $14.01 \%$, was the second most important fraction, followed by the carbonate fraction (10.08\%) and the reducible fraction (6.51\%). The

Page $4 / 16$ 
exchangeable fraction was found to be the least contributor for $\mathrm{Pb}$, accounting for $0.03 \%$. It suggested that $\mathrm{Pb}$ was primarily occluded in Fe-Mn oxides forms, besides the residual fraction. This result is in line with the previous results that the high affinity of $\mathrm{Pb}$ for Fe oxides makes it possible for them to act as long-term sinks for $\mathrm{Pb}$ (Banat et al. 2005).

Zinc: The residual fraction of $\mathrm{Zn}$ accounted for $24.25-54.93 \%$, and the exchangeable form was $0.02-0.93 \%$. The dominating chemical form for $\mathrm{Zn}$ was the residual fraction $(42.22 \%)$, and the carbonate $(28.20 \%)$ was of the secondary important. A proportion of $\mathrm{Zn}$ was found to be oxidizable (19.37\%) and reducible (9.98\%), and the exchangeable fraction made up the smallest proportion ( $0.22 \%)$. High carbonate fraction was observed in Fig.2. It indicated that Zn was strongly associated with carbonate in RDs particles. Lee et al (2015) reported that $\mathrm{Pb}$ in carbonate phase $\left(\mathrm{ZnCO}_{3}\right)$ was observed through scanning electron microscope (SEM) equipped with energy dispersive $X$-ray spectroscopy (EDS). The sum unstable fractions of carbonate, oxidizable and reducible accounted for a high amount (57.55\%). The result was in accordance with Świetlik et al. (2015), who proposed an assumption that a direction of changes in Zn distribution pattern was determined under sequence environment conditions changes.

Nickel: Ni was generally found in its residual form, accounting for average $80.94 \%$. The exchangeable fraction, the concentration associated with the carbonate, with the Fe-Mn oxides and organic matter represent $0.17,4.05,6.27$, and $8.57 \%$ of the total content, respectively.

Chromium: The $\mathrm{Cr}$ in RDs samples particles was associated predominantly with the forms of residual forms (91.43\%), whereas the exchangeable, carbonate and organic-bound fractions were almost negligible $(<5 \%)$. In this study, $\mathrm{Ni}$ and $\mathrm{Cr}$ were generally found in their residual fraction, with an average value of $80.94 \%$ and $91.43 \%$, respectively. In summary, the percentages of Fe-Mn oxide fraction of Cd, $\mathrm{Pb}$, and $\mathrm{Zn}$ were higher than the other three metals. The proportion of residual $\mathrm{Cr}$ and Ni were higher than the other metals. Cu had higher organic-bound forms.

The relatively bioavailability of metals decreased in the order: exchangeable>bound to carbonate>bound to Fe-Mn oxide>bound to organic>residual fractions, and the top four fractions represented high mobility and potential bioavailability. In particular, the exchangeable fraction was considered readily mobile and bioavailable in the environment. Fraction of exchangeable is the easiest adsorbed by organisms of all the five fractions. Bound to carbonate can dissolved easily by water and adsorbed by organisms. Bound to Fe-Mn oxide can be released to solution when $\mathrm{Eh}$ or $\mathrm{pH}$ has changed. Otherwise bound to organic matter is not easily adsorbed by organisms, and residual fraction is invalidation to organisms. Except the resident fraction, the other four fractions of heavy metals can be leached, which were be regarded as the potential risk forms. In summary, the sum of top four fractions accounted for $30.67 \%$ for $\mathrm{Cd}, 8.7 \%$ for $\mathrm{Cr}, 39.16 \%$ for $\mathrm{Cu}, 19.06$ for $\mathrm{Ni}, 30.73 \%$ for $\mathrm{Pb}$ and $57.78 \%$ for $\mathrm{Zn}$, respectively. The result implied the high mobility and potential bioavailability in the following order: $\mathrm{Cr}<\mathrm{Ni}<\mathrm{Cd}<\mathrm{Pb}<\mathrm{Cu}<\mathrm{Zn}$. Thus, the chemical speciation except residual fraction with relatively stable heavy metals can be used an index of heavy metals active state. Clearly, the sum four fractions $(\mathrm{F} 1+\mathrm{F} 2+\mathrm{F} 3+\mathrm{F} 4)$ of $\mathrm{Cd}, \mathrm{Cu}, \mathrm{Pb}$ and $\mathrm{Zn}$ almost accounted more than $30 \%$ of total heavy metals, meaning that these four elements have high available concentrations, especially for the $\mathrm{Zn}$ element. This result shows that highly mobile metals and readily extractable fractions pose a high potential risk to the environment. The result was agreed with our previous study that heavy metals in RDs were moderate to high polluted and huge potential ecological risk (Xiao et al., 2020). That's may be the reason why high availability and mobility of the trace metal $\mathrm{Cd}, \mathrm{Cu}, \mathrm{Pb}$ and $\mathrm{Zn}$ named the "urban heavy metal" (De Miguel et al. 1997). The elements $\mathrm{Cr}$ and $\mathrm{Ni}$ are predominantly in resident fraction, indicating that the $\mathrm{Cr}$ and $\mathrm{Ni}$ have low potential toxic. In summary, the metals $\mathrm{Cd}, \mathrm{Cu}, \mathrm{Pb}$ and $\mathrm{Zn}$ were primarily associated with non-residual fraction and thus were classified as potentially mobile elements. The $\mathrm{Ni}$ and $\mathrm{Cr}$ were classified as immobile elements because they were strongly bound to the residual fraction.

\subsection{Risk assessment of heavy metals in RDs}

The result of TCLP, EDTA, and $0.1 \mathrm{M} \mathrm{CaCl}_{2}$ extractable content heavy metals in RDs samples was displayed in Fig.3. The mean concentration of PBET-extractable $\mathrm{Cd}, \mathrm{Cr}, \mathrm{Cu}, \mathrm{Ni}, \mathrm{Pb}$ and $\mathrm{Zn}$ are $0.14,0.90,1.10,1.14,2.65$, and $100.65 \mathrm{mg}^{\mathrm{kg}}{ }^{-1}$, respectively. PBET extraction is widely applied to assess the bioaccessibility of the heavy metals in dust and sediment. The results of TCLP-extractable contents $\mathrm{Cd}, \mathrm{Cr}, \mathrm{Cu}, \mathrm{Ni}, \mathrm{Pb}$ and $\mathrm{Zn}$ are $0.06,0.17,0.29,0.87,0.66$, and $48.12 \mathrm{mg} \cdot \mathrm{kg}^{-1}$, respectively. The TCLP mothed is often used to evaluate the potential environment risk. The concentration of $\mathrm{CaCl}_{2}$-extractable $\mathrm{Cd}, \mathrm{Cr}, \mathrm{Cu}, \mathrm{Ni}, \mathrm{Pb}$ and $\mathrm{Zn}$ are generally low, with an average value of $0.01,0.02,0.18,0.05,0.06$, and $0.39 \mathrm{mg} \cdot \mathrm{kg}^{-1}$, respectively. Obviously, the three different extraction got diverse concentrations of heavy metals in RDs particles. Due to the alkalinity of the RDs particles (average $\mathrm{pH}>8.66$ ), $\mathrm{CaCl}_{2}$-extractable content heavy metals were low and almost negligible. The results also revealed that the $\mathrm{CaCl}_{2}$ gave the lowest extraction concentrations whereas the PBET procedure provided the highest extraction concentration. The extractability of heavy metals by the three methods tended to increase in the 
following order: $\mathrm{CaCl}_{2}<\mathrm{TCLP}<\mathrm{PBET}$. It demonstrated that the concentrations of heavy metals leached by PBET were much higher than TCLP and $\mathrm{CaCl}_{2}$. The result indicated that PBET contained a much strong ability to extract heavy metals. Similar result for PBETextraction bioavailability was also reported by Luo et al. (2012), who found that the mobility of Cu and Zn in PBET-extraction explained 93.4 and $88.2 \%$ of variations in the amount of $\mathrm{Cu}$ and $\mathrm{Zn}$.

In addition, the concentrations of $\mathrm{CaCl}_{2}$ - TCLP-, and PBET extractable heavy metals are calculated as leachability ratio to evaluate heavy metals mobility, leachability, and bioaccessibility (Fig. 4). The extraction percentage by PBET, TCLP and CaCl 2 represents human bioaccessibility, toxicity and mobility proportion of heavy metals in RDs particles. The mean PBET extractability is $13.76 \%, 0.63 \%, 2.35 \%$, $4.00 \%, 4.22 \%$ and $30.91 \%$ for $\mathrm{Cd}, \mathrm{Cr}, \mathrm{Cu}, \mathrm{Ni}, \mathrm{Pb}$ and $\mathrm{Zn}$, respectively. The $\mathrm{Cr}$ exhibits the lowest leachability among the investigated metals, which agreed with the fact that $\mathrm{Cr}$ is dominant in the residual fraction. Otherwise, $\mathrm{Cd}$ and $\mathrm{Zn}$ have higher PBET leachability values, indicating higher potential risks to the environment and human health. In summary, the average leachability of heavy metals follows the order $\mathrm{Zn}>\mathrm{Cd}>\mathrm{Pb}>\mathrm{Ni}>\mathrm{Cu}>\mathrm{Cr}$. The mean TCLP extractability is 5.72\%, 0.12\%, 0.57\%, 3.00\%, 1.04\%, and 15.05\% for Cd, Cr, Cu, Ni, Pb and $\mathrm{Zn}$, respectively. The highest leachability was observed in $\mathrm{Zn}$, followed by $\mathrm{Cd}$. The leachability of $\mathrm{Cr}$, $\mathrm{Cu}$ and $\mathrm{Pb}$ was almost less than $1 \%$, indicating that these three metals are hard removed from RDs particles. It also means relative low hazardous for environment. The average $\mathrm{CaCl}_{2}$ extractability is $0.64 \%$ for $\mathrm{Cd}, 0.01 \%$ for $\mathrm{Cr}, 0.35 \%$ for $\mathrm{Cu}, 0.19 \%$ for $\mathrm{Ni}, 0.11 \%$ for $\mathrm{Pb}$ and $0.11 \%$ for $\mathrm{Zn}$, respectively.

There are great differences in the bioavailability of the different metals. The metal Zn and Cd have higher bioavailability, while relative lower values are recorded for $\mathrm{Cr}$ and $\mathrm{Ni}$. Similarly, the bioavailability estimated by PBET extraction is much higher than the leachability estimated by TCLP and $\mathrm{CaCl}_{2}$ extraction in each corresponding heavy metal element. RDs particles are small and ubiquity, which can easily be uptake by food ingestion, dermal contact, or breathing. Therefore, the high leachability of heavy metals in RDs particles indicated high potential hazardous to the human health and environment safe. Overall, the bioavailability of $\mathrm{Cr}$ and $\mathrm{Ni}$ is low, indicating that $\mathrm{Cr}$ and $\mathrm{Ni}$ have low potential hazard, which is in accordance to the chemical results that $\mathrm{Cr}$ and $\mathrm{Ni}$ are main in residual fraction. However, the urban metals of $\mathrm{Cd}, \mathrm{Cu}, \mathrm{Pb}$ and $\mathrm{Zn}$ containing high bioavailability in RDs particles should be taken into account their huge potential toxicity and mobility.

\subsection{Relationship between availability and chemical fractions}

As mentioned above, the available, mobility and toxicity of heavy metals bound in RDs are largely depended on their chemical speciation. Better to understand the chemical fraction contributions to bioaccessible heavy metals, a relationship between availability and different chemical fractions, including sum of the first two fractions (F1+F2, SUM2), the first three fractions (F1+F2+F3, SUM3) and the first four fractions (F1+F2+F3+F4, SUM4), was carried out in table 2. The residual fraction (F5) was not included due to its least bioavailability. Except $\mathrm{Cu}$, there is a significantly positive relationship between SUM2, SUM3, and SUM4 and the concentration of TCLP- and PBETextractable metals. However, there was almost no significant relationship between SUM2, SUM3, and SUM4 and the concentration of $\mathrm{CaCl}_{2}$-extractable metals. In addition, there is a significant relationship between $\mathrm{CaCl}_{2}$-extraction and SUM3 and SUM4 for Zn, respectively. For $\mathrm{Pb}$, the correlation coefficient was extremely high between PBET-extractable and chemical fractions, with $\mathrm{R}^{2} 0.888$ for SUM2, 0.929 for SUM3 and 0.932 for SUM4, respectively. It suggested bioaccessibility Pb mainly came from SUM4. Similar founding was also observed in TCLP-extractable Pb. For Zn, the highest correlation coefficient was observed between PBET-extractable and SUM4, while the satisfactory correlation of $R^{2}(0.614)$ was found between TCLP-extractable solution and SUM2, followed by SUM3 with $R^{2} 0.517$. The results suggested that TCLP-extractable Zn mainly originated from Zn in exchangeable and carbonate bound, while PBET-extractable Zn came from $\mathrm{Zn}$ in SUM4. Comparison with the chemical fractions and single extractable method, the PBET has much more ability to dissolve heavy metals in RDs particles.

In general, the relationship between chemical speciation and extractable tests can reflect the potential ecological risk of heavy metals in RDs, which can be better to reflect the bioavailability of heavy metals in RDs particles. The similar result was found by Li et al. (2015a), who found that the variation in Pb bioaccessibility should be explained by Pb in SUM2 and SUM3, respectively. Results imply that mobility or bioavailability of heavy metals is highly correlated to their chemical fractions in RDs particles. In a word, chemical fractions of heavy metals in RDs particles controlled their dissolution and toxicity.

\subsection{Environment significance}

Bioavailability and leachability of heavy metals could be controlled by many RDs properties, such as the total contents, pH, Ec, PSD, organic carbon, mineral phases, and so on. Table 2 shows the results of stepwise multiple linear regression analysis equation. The influence factors on heavy metal bioavailability can be clearly observed in these equations. The result implied that the heavy metals Cd, $\mathrm{Cr}, \mathrm{Cu}, \mathrm{Ni}, \mathrm{Pb}$, and $\mathrm{Zn}$ extracted by PBET were significantly affected by the total concentration of corresponding metals. Each regression 
equation was composed of total concentration and other RDs factors. Obviously, the extractable heavy metals in RDs samples were main determined by the total heavy metals contents, which was in according the other studies (Li and Zhang 2013, Rodrigues et al. 2013), showing high correlation between total contents and extractable ones. The total content of heavy metals in RDs was as a source pool that could be the one of main factors controlling the leachability of heavy metals. In addition, there was one point should be pointed out that the $\mathrm{Pb}$ regression equations by $\mathrm{CaCl}_{2}$ could not be built. It might be the high average $\mathrm{pH}$ value (average 8.44) of $\mathrm{RDs}$ particles, limiting element $\mathrm{Pb}$ dissolving from the solid phase surface. Exchangeable $\mathrm{Pb}$ element is also hard to remove from the RDs samples at the high $\mathrm{pH}$ situation. According to the result of stepwise multiple linear regression analysis, the main factors in limiting heavy metals dissolving from RDs were the parameters of $\mathrm{pH}$, organic carbon, carbonate, and the corresponding metal element. Compared with the regression equations of three extractable methods, PBET method was the best choice in high correlation coefficient to predict the relationship between the heavy metals concentrations and extractable concentration. The similar results were found by Li et al. (2013) and Rodrigues et al. (2013), who both found the extraction of PBET could well predict the $\mathrm{Cu}, \mathrm{Zn}$ and Pb bioaccessibility. The association of $\mathrm{Cu}, \mathrm{Pb}$, and $\mathrm{Zn}$ in sediment particles has already been observed and these elements have been identified as typical "urban" metals by some authors (De Miguel et al. 1997).

It suggested that RDs properties, besides the total heavy metals, did influence heavy metals bioavailability (Li and Zhang 2013; Mendoza et al. 2017; Świetlik et al. 2015). In general, the high content of $\mathrm{H}^{+}$could dissolve the heavy metals from RDs to environment surroundings, causing high potential risks. It suggested that these heavy metals in RDs might release easily by acid rain leaching. The results implied that heavy metals in RDs had higher potential risks in acid rain area than that in non-acid rain area. Otherwise, the extremely high content of total carbon in RDs could complex or adsorb the heavy metals, which could affect the dissolution and movement of heavy metals in RDs as well (He and Zhang, 2009; Zong et al., 2016b). What's more, heavy metals could be immobilized stably in some mineral particles, such as carbonate, sulfide and phosphide, posing the low bioavailability. This part of heavy metals in RDs contain relative low toxicity and bioavailability, almost referenced residual fraction. Meanwhile, particle size distribution could affected heavy metals' distribution and bioavailability (Zong et al., 2016b). The heavy metals were enriched most seriously in the finest particles, containing the highest potential risk, which were the main source of potentially toxic metals (Zong et al., 2016b). It was due to the basic properties of finest particles with high total carbon content, negative charge and high BET.

Generally, the mobility and bioavailability of heavy metals in RDs decreased approximately with the order of extraction sequence due to the strength of binding ability decreasing (Tessier et al. 1979). Thus, exchangeable (F1) and carbonate-bound fraction (F2) are regarded as potentially mobile or bioavailable fractions, while the reducible (F3) and oxidization fractions (F4) are recognized as the low mobile fractions (Lee et al. 2005). The heavy meals in residual fraction (F5) represented the least mobile fraction. The mobility of heavy metals in RDs based on the sequence extraction tended to decrease in the following order: $\mathrm{Zn}>\mathrm{Cd}>\mathrm{Pb}>\mathrm{Ni}>\mathrm{Cu}>\mathrm{Cr}$. Obviously, $\mathrm{Zn}, \mathrm{Cd}$ and $\mathrm{Pb}$ contain higher mobility and can be more harmful to the environment. In addition, the proportion $\mathrm{F} 2+\mathrm{F} 3$ of $\mathrm{Zn}$ and $\mathrm{Pb}$ in $\mathrm{RDs}$ is relative high, with the average value of $57.58 \%$ and $28.19 \%$, respectively. It indicates that $\mathrm{Zn}$ and $\mathrm{Pb}$ can be released easily when oxidation conditions are changed into slightly reducing conditions. This is in agreement with our previous founding for urban top soil (Zong et al. 2016a). In case of $\mathrm{Cu}$, the chemical fraction predominated in F4 fraction. It suggested that $\mathrm{Cu}$ can leach into the surrounding environment in strong oxidization or reduction conditions.

In order to evaluate the heavy metal mobility, the mobility index $\mathrm{K}$ was defined, which was calculated on the basis of the ratio of exchangeable, carbonate-bound fraction to the sum five fractions (Świetlik et al. 2015; Zong et al. 2016a). The results indicated that the $\mathrm{K}$ value for $\mathrm{Zn}$ is the highest, with the average value of $28.44 \%$. $\mathrm{Zn}$ is identified as being the most mobile of the elements in RDs, followed by $\mathrm{Cd}(15.13 \%), \mathrm{Pb}(10.21 \%), \mathrm{Ni}(4.22 \%), \mathrm{Cu}(3.46 \%)$ and $\mathrm{Cr}(1.09 \%)$. Therefore, it can conclude that $\mathrm{Zn}$ is the most mobile metal in RDs while $\mathrm{Cr}$ is the least mobile metal with a low risk for urban environment ecosystem. Based on the $\mathrm{K}$ value, the metal $\mathrm{Zn}, \mathrm{Cd}$, and $\mathrm{Pb}$ can be classified as highly mobile elements group, and $\mathrm{Ni}$ and $\mathrm{Cr}$ are classified as immobile elements one. Obviously, the chemical fractions of highly mobile elements group were high in F1 and F2, while the proportion of F5 in the immobile element group is overwhelming (more than $80 \%$ ). In particular, the $\mathrm{Cu}$ is classified as less mobile element group because of its predominantly chemical fraction in the organicbound. It should be pointed out that the highly mobile heavy metals had greater environment ecosystem and human health risks. Meanwhile, the less mobile element $\mathrm{Cu}$ also has potentially risk depending on the strong oxidizing or strong reducing environment conditions. The immobile elements have relative low environment risk due to these elements fixed within their crystal structure.

\section{Conclusions}

The sequential chemical extraction revealed that the relative percentage of $\mathrm{Cd}$ and $\mathrm{Zn}$ tended to increase in the order: $\mathrm{F} 5>\mathrm{F} 2>\mathrm{F} 3>\mathrm{F} 4>\mathrm{F} 1$. The percentage of $\mathrm{Cu}$ displayed in the following order: $\mathrm{F} 5>\mathrm{F} 4>\mathrm{F} 2>\mathrm{F} 1>\mathrm{F} 3$. Extremely high percentage was observed in organic-bound. The 
average percentage distribution for $\mathrm{Pb}$ tended to increase in the order: $\mathrm{F} 5>\mathrm{F} 3>\mathrm{F} 2>\mathrm{F} 4>\mathrm{F} 1$. $\mathrm{Cr}$ and $\mathrm{Ni}$ contained high percentage in residual fraction, and were classified as immobile elements. The metals $\mathrm{Cd}, \mathrm{Cu}, \mathrm{Pb}$ and $\mathrm{Zn}$ were primarily associated with non-residual fraction and classified as potentially mobile elements. The percentage of metals bound with non-residual fractions accounted for over $57.78 \%$ for $\mathrm{Zn}, 39.16 \%$ for $\mathrm{Cu}, 30.67 \%$ for $\mathrm{Cd}, 30.73 \%$ for $\mathrm{Pb}, 19.06$ for $\mathrm{Ni}$, and $8.7 \%$ for $\mathrm{Cr}$, respectively. PBET contained a much strong ability to extract heavy metals, followed by TCLP and $\mathrm{CaCl}_{2}$. The leachability of heavy metals decreased in the order: $\mathrm{Zn}>\mathrm{Cd}>\mathrm{Pb} \approx \mathrm{Ni}>\mathrm{Cu}>\mathrm{Cr}$. There was a significantly relationship between PBET, TCLP-test and bioavailable parts (F1, F2, F3 and F4), respectively. Thus, PBET and TCLP are available methods to reflect and evaluate the potential ecological risk of heavy metals in RDs. The results of multiple linear regression analysis indicated that PBET was a good method to predict the relationship between extractable heavy metals and RDs characterization properties, especially the heavy metals total concentration.

\section{Declarations}

\section{Author contribution}

Yutong Zong (first author): investigation, methodology, data curation, writing - original draft, review \& editing. Xiao Qing (co first author): investigation, methodology, data curation, writing-original draft. Zaffar Malik (coauthor): review and editing. Shenggao Lu (corresponding author): conceptualization, project administration, supervision, funding acquisition, writing - review \& editing. All authors read and approved the final manuscript

\section{Funding}

This research was supported by National Key R \& D Program of China (2016YFD0800401), the National Natural Science Foundation of China (41907066), and the Postdoctoral Science Foundation of China (2018M630681).

\section{Data Availability}

The dataset used and/or analyzed in this study are available from the corresponding author on reasonable request.

Consent to participate Not applicable.

Consent for publication Not applicable.

Ethics approval Not applicable.

Competing interests The authors declare no competing interests.

\section{References}

1. Banat KM, Howari FM, and Al-Hamad AA. 2005. Heavy metals in urban soils of central Jordan: Should we worry about their environmental risks? Environ Res 97(3): 258-273.

2. Barrett JES, Taylor KG, Hudson-Edwards KA, et al. 2010. Solid-Phase Speciation of Pb in Urban Road Dust Sediment: A XANES and EXAFS Study. Environ Sci Technol 44(8): 2940-2946.

3. De Miguel E, Iribarren I, Chacon E, et al. 2007. Risk-based evaluation of the exposure of children to trace elements in playgrounds in Madrid (Spain). Chemosphere 66(3): 505-513.

4. De Miguel E, Llamas JF, Chacon E, et al. 1997. Origin and patterns of distribution of trace elements in street dust: Unleaded petrol and urban lead. Atmos Environ 31(17): 2733-2740.

5. Duong TTT and Lee BK. 2009. Partitioning and mobility behavior of metals in road dusts from national-scale industrial areas in Korea. Atmos Environ 43(22-23): 3502-3509.

6. Ewen C, Anagnostopoulou MA, and Ward NI. 2009. Monitoring of heavy metal levels in roadside dusts of Thessaloniki, Greece in relation to motor vehicle traffic density and flow. Environ Monit Assess 157(1-4): 483-498.

7. Faiz Y, Tufail M, Javed MT, et al. 2009. Road dust pollution of $\mathrm{Cd}, \mathrm{Cu}, \mathrm{Ni}, \mathrm{Pb}$ and $\mathrm{Zn}$ along Islamabad Expressway, Pakistan. Microchem J 92(2): 186-192.

8. Fujiwara FG, Gomez DR, Dawidowski L, et al. 2011. Metals associated with airborne particulate matter in road dust and tree bark collected in a megacity (Buenos Aires, Argentina). Ecol Indic 11(2): 240-247. 
9. Gleyzes C, Tellier S, and Astruc M. 2002. Fractionation studies of trace elements in contaminated soils and sediments: a review of sequential extraction procedures. Trac-Trends Anal Chem 21(6-7): 451-467.

10. Gunawardana C, Goonetilleke A, Egodawatta P, et al. 2012. Source characterisation of road dust based on chemical and mineralogical composition. Chemosphere 87(2): 163-170.

11. Houba VJG, Novozamsky I, Huybregts AWM, et al. 1986. Comparison of Soil Extractions by $0.01 \mathrm{M} \mathrm{CaCl}_{2}$, by Euf and by Some Conventional Extraction Procedures. Plant Soil 96(3): 433-437.

12. Houba VJG, Temminghoff EJM, Gaikhorst GA, et al. 2000. Soil analysis procedures using $0.01 \mathrm{M}$ calcium chloride as extraction reagent. Commun Soil Sci Plant Anal 31(9-10): 1299-1396.

13. Kumar RS and Rajkumar P. 2014. Characterization of minerals in air dust particles in the state of Tamilnadu, India through FTIR, XRD and SEM analyses. Infrared Phys Technol 67: 30-41.

14. Lee PK, Choi BY, and Kang MJ. 2015. Assessment of mobility and bio-availability of heavy metals in dry depositions of Asian dust and implications for environmental risk. Chemosphere 119: 1411-1421.

15. Lee PK, Youm SJ, and Jo HY. 2013. Heavy metal concentrations and contamination levels from Asian dust and identification of sources: A case-study. Chemosphere 91(7): 1018-1025.

16. Lee PK, Yu YH, Yun ST. et al. 2005. Metal contamination and solid phase partitioning of metals in urban roadside sediments. Chemosphere 60(5): 672-689.

17. Li J, Li K, Cave M, et al. 2015a. Lead bioaccessibility in 12 contaminated soils from China: Correlation to lead relative bioavailability and lead in different fractions. J Hazard Mater 295: 55-62.

18. Li S, Li W, Li J, et al. 2015b. Arsenic bioaccessibility in contaminated soils: Coupling in vitro assays with sequential and $\mathrm{HNO}_{3}$ extraction. J Hazard Mater 295: 145-152.

19. Li Y and Zhang MK. 2013. A comparison of physiologically based extraction test (PBET) and single-extraction methods for release of $\mathrm{Cu}, \mathrm{Zn}$, and Pb from mildly acidic and alkali soils. Environ Sci Pollut Res 20(5): 3140-3148.

20. Lu X, Li LY, Wan L, et al. 2009. Contamination assessment of mercury and arsenic in roadway dust from Baoji, China. Atmos Environ 43(15):2489-2496.

21. Luo XS, Yu S, and Li XD. 2012. The mobility, bioavailability, and human bioaccessibility of trace metals in urban soils of Hong Kong. Appl Geochem 27(5): 995-1004.

22. Madrid F, Reinoso R, Florido MC, et al. 2007. Estimating the extractability of potentially toxic metals in urban soils: A comparison of several extracting solutions. Environ Pollut 147(3): 713-722.

23. Meers E, Samson R, Tack FMG, et al. 2007. Phytoavailability assessment of heavy metals in soils by single extractions and accumulation by Phaseolus vulgaris. Environ Exp Bot 60(3): 385-396.

24. Mendoza CJ, Mendoza CJ, Garrido RT, et al. 2017. Evaluation of the bioaccessible gastric and intestinal fractions of heavy metals in contaminated soils by means of a simple bioaccessibility extraction test. Chemosphere 176: 81-88.

25. Menzies NW, Donn MJ, and Kopittke PM. 2007. Evaluation of extractants for estimation of the phytoavailable trace metals in soils. Environ Pollut 145(1): 121-130.

26. Mercier G, Duchesne J, and Carles-Gibergues A. 2002. A simple and fast screening test to detect soils polluted by lead. Environ Pollut 118(3): 285-296.

27. Norouzi S, Khademi H, Cano AF, et al. 2016. Biomagnetic monitoring of heavy metals contamination in deposited atmospheric dust, a case study from Isfahan, Iran. J Environ Manage 173: 55-64.

28. Okorie A, Entwistle J, and Dean JR. 2012. Estimation of daily intake of potentially toxic elements from urban street dust and the role of oral bioaccessibility testing. Chemosphere 86(5): 460-467.

29. Peijnenburg WJGM, Zablotskaja M, and Vijver MG. 2007. Monitoring metals in terrestrial environments within a bioavailability framework and a focus on soil extraction. Ecotox Environ Safe 67(2): 163-179.

30. Peng JF, Song YH, Yuan P, et al. 2009. The remediation of heavy metals contaminated sediment. J Hazard Mater 161(2-3): 633-640.

31. Pereira PADP, Lopes WA, Carvalho LS, et al. 2007. Atmospheric concentrations and dry deposition fluxes of particulate trace metals in Salvador, Bahia, Brazil. Atmos Environ 41(36): 7837-7850.

32. Poggio L, Vrscaj B, Schulin R, et al. 2009. Metals pollution and human bioaccessibility of topsoils in Grugliasco (Italy). Environ Pollut 157(2): 680-689. 
33. Preciado HF and Li LY. 2006. Evaluation of metal loadings and bioavailability in air, water and soil along two highways of British Columbia, Canada. Water Air Soil Pollut 172(1-4): 81-108.

34. Rao CRM, Sahuquillo A, and Sanchez JFL. 2008. A review of the different methods applied in environmental geochemistry for single and sequential extraction of trace elements in soils and related materials. Water Air Soil Pollut 189(1-4): 291-333.

35. Rodrigues SM, Cruz N, Coelho C, et al. 2013. Duarte, A. C., Pereira, E., and Romkens, P. F. A. M., Risk assessment for Cd, Cu, Pb and Zn in urban soils: Chemical availability as the central concept. Environ Pollut 183: 234-242.

36. Ruby MV, Davis A, Schoof R, et al. 1996. Estimation of lead and arsenic bioavailability using a physiologically based extraction test. Environ. Sci. Technol 30(2): 422-430.

37. Shi GT, Chen ZL, Xu SY, et al. 2008. Potentially toxic metal contamination of urban soils and roadside dust in Shanghai, China. Environ Pollut 156(2): 251-260.

38. Świetlik R, Trojanowska M, Strzelecka M, et al. 2015. Fractionation and mobility of $\mathrm{Cu}, \mathrm{Fe}, \mathrm{Mn}, \mathrm{Pb}$ and $\mathrm{Zn}$ in the road dust retained on noise barriers along expressway - A potential tool for determining the effects of driving conditions on speciation of emitted particulate metals. Environ Pollut 196: 404-413.

39. Tessier A, Campbell PGC, and Bisson M. 1979. Sequential Extraction Procedure for the Speciation of Particulate Trace-Metals. Anal Chem 51(7): 844-851.

40. Tipping E, Rieuwerts J, Pan G, et al. 2003. The solid-solution partitioning of heavy metals ( $\mathrm{Cu}, \mathrm{Zn}, \mathrm{Cd}, \mathrm{Pb})$ in upland soils of England and Wales. Environ Pollut 125(2): 213-225.

41. U.S.EPA (United States Environmental Protection Agency). Method 1311: Toxicity Characteristic Leaching Procedure. 1992. https://19january2017snapshot.epa.gov/sites/production/files/2015-12/documents/1311.pdf.

42. Wei X, Gao B, Wang P, et al. 2015. Pollution characteristics and health risk assessment of heavy metals in street dusts from different functional areas in Beijing, China. Ecotox Environ Safe 112: 186-192.

43. Xiao Q, Zong YT, and Lu SG. 2015. Assessment of heavy metal pollution and human health risk in urban soils of steel industrial city (Anshan), Liaoning, Northeast China. Ecotox Environ Safe 120: 377-385.

44. Xiao Q, Zong YT, Malik Z, Lu, SG. 2020. Source identification and risk assessment of heavy metals in road dust of steel industrial city (Anshan), Liaoning, Northeast China. Human and Ecological Risk Assessment, 26(5), 1359-1378.

45. Zhang DL and Gong ZT. 2012. Soil survey laboratory method. Science Press. Beijing.

46. Zong YT, Xiao Q, and Lu SG. 2016a. Chemical fraction, leachability, and bioaccessibility of heavy metals in contaminated soils, Northeast China. Environ Sci Pollut Res 23(23): 24107-24114.

47. Zong YT, Xiao Q, and Lu SG. 2016b. Distribution, bioavailability, and leachability of heavy metals in soil particle size fractions of urban soils (northeastern China). Environ Sci Pollut Res 23(14): 14600-14607

48. Zong YT, Xiao Q, and Lu SG. 2017. Magnetic signature and source identification of heavy metal contamination in urban soils of steel industrial city, Northeast China. J Soils Sediments 17(1): 190-203

\section{Tables}

Table 1 Descriptive of basic properties in RDs samples 


\begin{tabular}{|llllllllllll|}
\hline & $\mathrm{TC}$ & $\mathrm{TP}$ & $\mathrm{TS}$ & $\mathrm{NH}_{4}{ }^{+}$ & $\mathrm{pH}$ & $\mathrm{Ec}$ & $\mathrm{CaCO}_{3}$ & $\mathrm{Fe}_{2} \mathrm{O}_{3}$ & $>50 \mu \mathrm{m}$ & $50-2 \mu \mathrm{m}$ & $<2 \mu \mathrm{m}$ \\
& $\left(\mathrm{g} \cdot \mathrm{kg}^{-1}\right)$ & $\left(\mathrm{g} \cdot \mathrm{kg}^{-1}\right)$ & $\left(\mathrm{g} \cdot \mathrm{kg}^{-1}\right)$ & $\left(\mathrm{g} \cdot \mathrm{kg}^{-1}\right)$ & & $\mu \mathrm{s} \cdot \mathrm{cm}^{-1}$ & $\%$ & $\%$ & $\mathrm{~g}^{-1} \mathrm{~kg}^{-1}$ & $\mathrm{~g} \cdot \mathrm{kg}^{-1}$ & $\mathrm{~g} \cdot \mathrm{kg}^{-1}$ \\
\hline Minimum & 16.91 & 0.06 & 0.33 & 0.02 & 7.29 & 1.16 & 1.99 & 6.26 & 351.62 & 57.52 & 34.43 \\
\hline Maximum & 216.61 & 0.55 & 2.06 & 0.84 & 10.19 & 1357 & 19.36 & 70.68 & 864.1 & 377.48 & 282.21 \\
\hline Range & 199.7 & 0.49 & 1.73 & 0.82 & 2.9 & 1355.84 & 17.37 & 64.42 & 512.48 & 319.96 & 247.78 \\
\hline Median & 39.05 & 0.27 & 0.66 & 0.13 & 8.43 & $3.80 \mathrm{E}+02$ & 9.88 & 14.01 & $5.98 \mathrm{E}+02$ & $2.47 \mathrm{E}+02$ & $1.63 \mathrm{E}+02$ \\
\hline Mean & 47.19 & 0.27 & 0.71 & 0.16 & 8.44 & $4.35 \mathrm{E}+02$ & 10.62 & 16.74 & $5.97 \mathrm{E}+02$ & $2.47 \mathrm{E}+02$ & $1.56 \mathrm{E}+02$ \\
\hline SD & 33.5 & 0.093 & 0.281 & 0.106 & 0.653 & $2.98 \mathrm{E}+02$ & 3.035 & 10.5 & $1.16 \mathrm{E}+02$ & $6.08 \mathrm{E}+01$ & $6.85 \mathrm{E}+01$ \\
\hline Skewness & 2.734 & 0.475 & 2.458 & 3.7 & 0.411 & 0.975 & 0.463 & 2.611 & 0.018 & -0.047 & 0.166 \\
\hline Kurtosis & 8.9 & 0.147 & 8.788 & 20.036 & -0.089 & 0.689 & 0.763 & 8.894 & -0.581 & 0.35 & -0.775 \\
\hline
\end{tabular}

TC: total carbon, TP: total phosphate, TS: total sulfur.

Table 2 Correlation between chemical fractions and concentrations of heavy metals extraction tests in Road dust

\begin{tabular}{|c|c|c|c|c|}
\hline Metals & Methods & SUM2 & SUM3 & SUM4 \\
\hline \multirow[t]{2}{*}{ Cd } & TCLP & $0.706^{\star \star}$ & $0.713^{* \star}$ & $0.711^{\star \star}$ \\
\hline & PBET & $0.719^{\star \star}$ & $0.792^{\star \star}$ & $0.752^{\star \star}$ \\
\hline \multirow[t]{2}{*}{$\mathrm{Cu}$} & TCLP & -0.037 & -0.037 & 0.041 \\
\hline & PBET & 0.038 & 0.032 & -0.028 \\
\hline \multirow[t]{2}{*}{$\mathrm{Ni}$} & TCLP & $0.643^{\star \star}$ & $0.715^{\star \star}$ & $0.612^{\star \star}$ \\
\hline & PBET & $0.609^{* *}$ & $0.594^{\star \star}$ & $0.454^{*}$ \\
\hline \multirow[t]{2}{*}{$\mathrm{Pb}$} & TCLP & $0.658^{* \star}$ & $0.820^{\star \star}$ & $0.844^{* \star}$ \\
\hline & PBET & $0.888^{* *}$ & $0.929^{* \star}$ & $0.932^{\star \star}$ \\
\hline \multirow[t]{2}{*}{ Zn } & TCLP & $0.614^{\star \star}$ & $0.557^{\star}$ & $0.548^{*}$ \\
\hline & PBET & $0.666^{* *}$ & $0.720^{\star \star}$ & $0.761^{\star \star}$ \\
\hline
\end{tabular}

**. Correlation is significant at the 0.01 level.

*. Correlation is significant at the 0.05 level.

Table 3 Stepwise multiple linear regression analysis 


\begin{tabular}{|c|c|c|c|}
\hline Methods & Metals & Regression model & $\mathrm{R}^{2}$ \\
\hline \multirow[t]{6}{*}{$\mathrm{CaCl}_{2}$} & $\mathrm{Cd}$ & $\mathrm{Y}=0.331 \mathrm{Cd}+0.531 \mathrm{TP}-4.335 \mathrm{Fe}_{2} \mathrm{O}_{3}+0.830$ & 0.638 \\
\hline & $\mathrm{Cr}$ & $\mathrm{Y}=-0.665 \mathrm{Fe}_{2} \mathrm{O}_{3}-0.367 \mathrm{CaCO}_{3}-0.928 \mathrm{NH}_{4}{ }^{+}+2.430$ & 0.657 \\
\hline & $\mathrm{Cu}$ & $Y=0.504 \mathrm{Cu}+0.3 \mathrm{NH}_{4}^{+}-0.480 T S-1.475$ & 0.698 \\
\hline & $\mathrm{Ni}$ & $\mathrm{Y}=0.662 \mathrm{Ni}-0.240 \mathrm{Fe}_{2} \mathrm{O}_{3}-2.622 \mathrm{pH}+0.288$ & 0.605 \\
\hline & $\mathrm{Pb}$ & $\mathrm{N}$ & \\
\hline & Zn & $Y=1.449 Z n-0.793 P M-10.385 p H+26.834$ & 0.685 \\
\hline \multirow[t]{6}{*}{ TCLP } & $\mathrm{Cd}$ & $Y=0.807 \mathrm{Cd}+0.598 \mathrm{TC}-0.423 \mathrm{PM} 2-1.344$ & 0.626 \\
\hline & $\mathrm{Cr}$ & $Y=0.981 \mathrm{Cr}-2.726$ & 0.739 \\
\hline & $\mathrm{Cu}$ & $\mathrm{Y}=0.859 \mathrm{Cu}-0.262 \mathrm{TS}+0.133 \mathrm{NH}_{4}{ }^{+}-1.286$ & 0.740 \\
\hline & $\mathrm{Ni}$ & $Y=0.820 \mathrm{Ni}-0.707 \mathrm{CaCO}_{3}+0.278 \mathrm{TP}-0.408$ & 0.636 \\
\hline & $\mathrm{Pb}$ & $\mathrm{Y}=1.474 \mathrm{~Pb}-1.068 \mathrm{CaCO}_{3}-0.612 \mathrm{TS}-1.907$ & 0.768 \\
\hline & $\mathrm{Zn}$ & $Y=1.2661 Z n-2.906 p H+0.382 \mathrm{NH}_{4}{ }^{+}-0.433 T C+2.164$ & 0.731 \\
\hline \multirow[t]{6}{*}{ PBET } & $\mathrm{Cd}$ & $Y=0.782 \mathrm{Cd}-1.842 \mathrm{pH}-0.153 \mathrm{PM}+21.099$ & 0.702 \\
\hline & $\mathrm{Cr}$ & $\mathrm{Y}=0.609 \mathrm{Cr}+0.495 \mathrm{TS}-0.784 \mathrm{pH}-0.563$ & 0.709 \\
\hline & $\mathrm{Cu}$ & $\mathrm{Y}=0.692 \mathrm{Cu}+0.387 \mathrm{TC}-0.504 \mathrm{TS}-0.280 \mathrm{CaCO}_{3}-1.515$ & 0.695 \\
\hline & $\mathrm{Ni}$ & $\mathrm{Y}=0.860 \mathrm{Ni}+0.133 \mathrm{NH}_{4}{ }^{+}-0.902 \mathrm{pH}-0.280$ & 0.688 \\
\hline & $\mathrm{Pb}$ & $\mathrm{Y}=0.988 \mathrm{~Pb}-0.255 \mathrm{CaCO}_{3}+0.720 \mathrm{pH}-1.772$ & 0.876 \\
\hline & $\mathrm{Zn}$ & $\mathrm{Y}=0.944 \mathrm{Zn}-1.321 \mathrm{pH}-0.250 \mathrm{CaCO}_{3}+1.079$ & 0.865 \\
\hline
\end{tabular}

$\mathrm{N}$ means no regression equation was built.

\section{Figures}




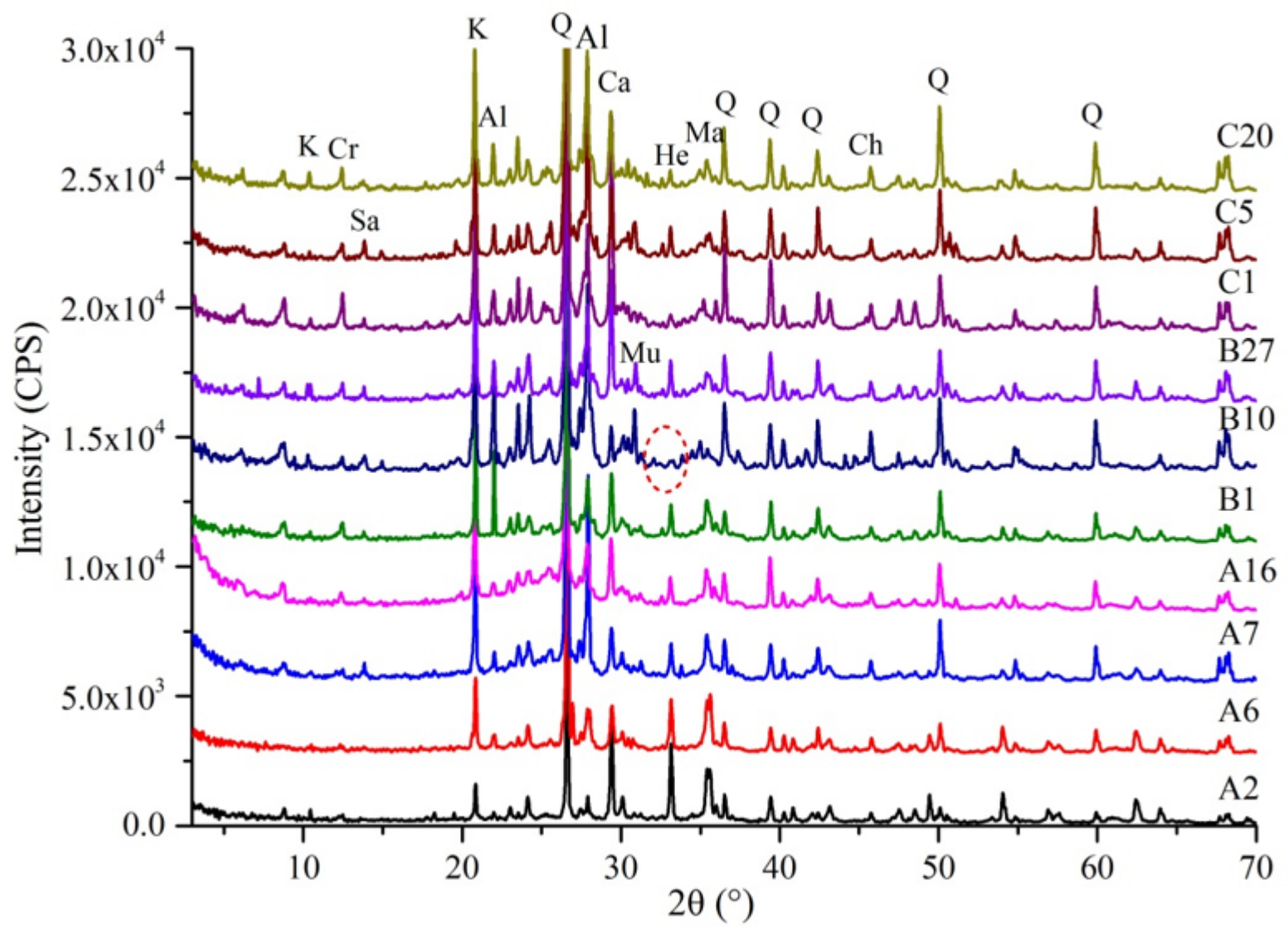

Figure 1

X-ray diffraction patterns of representative road dust from Anshan city. Ch. chlorite; He. hematite; Ca. calcite; M. magnetite; K. kaolinite; Mu. muscovite; Q. quartz; Al. albite. Cr. cronstedtite; Sa. sanidine. 


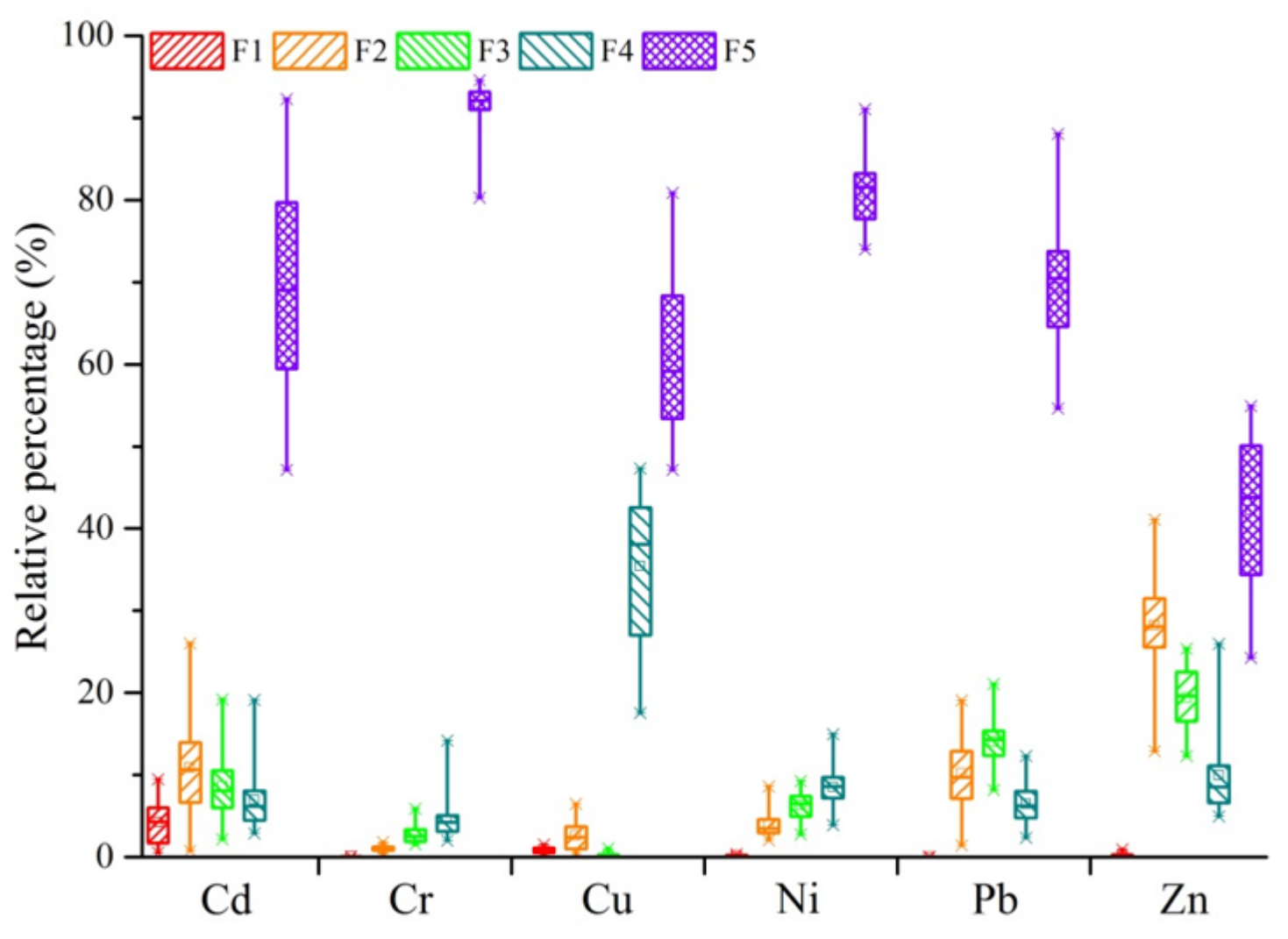

\section{Figure 2}

Chemical fractions of heavy metals ( $\mathrm{Cd}, \mathrm{Cr}, \mathrm{Cu}, \mathrm{Ni}, \mathrm{Pb}$ and $\mathrm{Zn}$ ) in road dust. F1 water-soluble/exchangeable, $\mathrm{F} 2$ carbonate-bound, $\mathrm{F} 3 \mathrm{Fe}$ Mn oxides-bound, F4 organic-bound, and F5 residual. Each box plot includes the median value, mean, lower and upper hinges, 5th and 95th percentages, and outliers. 


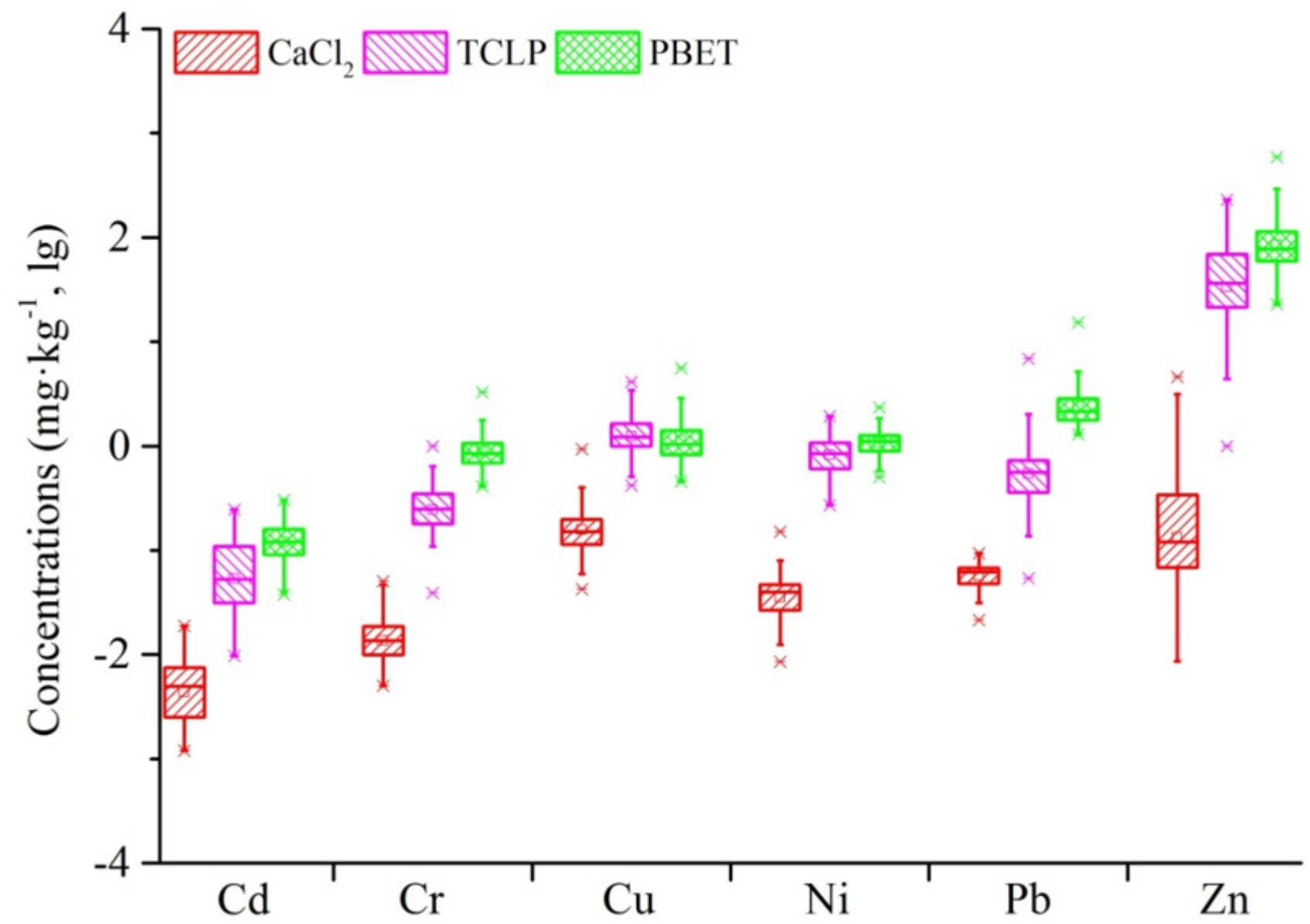

Figure 3

Concentration of heavy metals $(\mathrm{Cd}, \mathrm{Cr}, \mathrm{Cu}, \mathrm{Ni}, \mathrm{Pb}$ and $\mathrm{Zn}$ ) extracted by $\mathrm{CaCl} 2, \mathrm{TCLP}$ and PBET in road dust. The value of concentration is taken by the logarithm. 


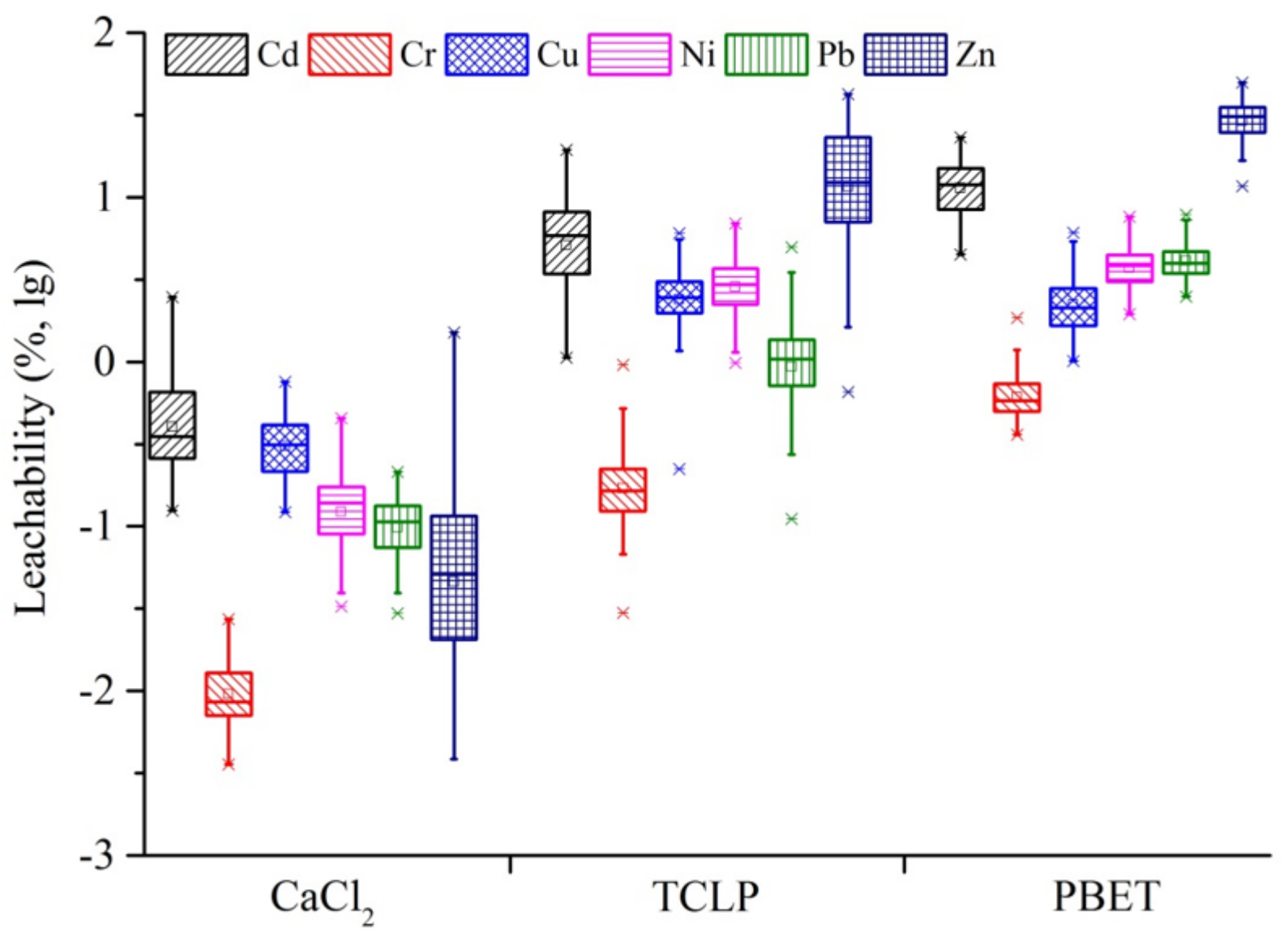

Figure 4

Leachability of heavy metals with respect to its total concentration in RDs. The value of leachability is taken by the logarithm.

\section{Supplementary Files}

This is a list of supplementary files associated with this preprint. Click to download.

- Tables1.docx 